УДК 343.265:343.35

DOI https://doi.org/10.51989/NUL.2021.5.21

\title{
ЗВІЛЬНЕННЯ ВІД ВІДБУВАННЯ ПОКАРАННЯ З ВИПРОБУВАННЯМ ЗА ВЧИНЕННЯ КОРУПЦІЙНИХ КРИМІНАЛЬНИХ ПРАВОПОРУШЕНЬ І КРИМІНАЛЬНИХ ПРАВОПОРУШЕНЬ, ПОВ'ЯЗАНИХ ІЗ КОРУПЦІЄЮ, НА ПІДСТАВІ УГОД
}

\author{
Юріков Олександр Олександрович, \\ ORCID: 0000-0002-6900-6887 \\ викладач циклу загальних та кримінально-правових дисциплін \\ Київського центру первинної професійної підготовки «Академія поліції» \\ Навчально-наукового інституту № 1 \\ Національної академії внутрішніх справ
}

У статті проаналізовано проблемні питання звільнення від відбування покарання з випробуванням за вчинення корупційних кримінальних правопорушень і кримінальних правопорушень, пов'язаних із корупцією, на підставі угоди про примирення чи про визнання винуватості.

Виявлено колізії деяких положень Кримінального кодексу України та Кримінального процесуального кодексу України щодо звільнення від відбування покарання з випробуванням за вчинення корупційних кримінальних правопорушень і кримінальних правопорушень, пов'язаних із корупцією, на підставі угод.

Вивчено судову практику Вищого спеціалізованого суду України з розгляду цивільних і кримінальних справ, а також Вищого антикорупційного суду з окресленого питання, на підставі чого аргументовано, що судові органи розробили правову позицію, згідно з якою під час звільнення від відбування покарання з випробуванням на підставі укладеної угоди про примирення чи про визнання винуватості не варто враховувати положення частини 1 статті 75 Кримінального кодексу України, а тому в разі затвердження зазначеної вище угоди можна звільнити особу від відбування покарання із встановленням випробувального строку, зокрема в разі засудження ії за корупційне кримінальне правопорушення або кримінальне правопорушення, пов'язане з корупцією.

За результатами аналізу законопроєкту від 23 лютого 2021 року № 5137 «Про внесення змін до Кримінального кодексу України та Кримінального процесуального кодексу України з метою невідворотності покарання за корупційні кримінальні правопорушення» обґрунтовано, що запропоновані законодавцем зміни до Кримінального кодексу України та Кримінального процесуального кодексу України вже $\epsilon$ застарілими, не цілком відповідають потребам правозастосування у сфері протидії корупції.

3 огляду на спрямованість антикорупційної політики держави, запропоновано зміни до Кримінального кодексу України та Кримінального процесуального кодексу України з метою вирішення питання щодо однозначного тлумачення статті 75 Кримінального кодексу України, а також правильного застосування положень кримінального і кримінального процесуального законодавства України з метою протидії корупційним виявам шляхом установлення абсолютної заборони на звільнення особи, яка вчинила корупційне кримінальне правопорушення чи кримінальне правопорушення, пов'язане з корупцією, від кримінальної відповідальності, покарання чи його відбування.

Ключові слова: кримінальне правопорушення, угода, примирення, винуватість, корупція, кримінальна відповідальність, покарання, звільнення, випробування, іспитовий строк.

\section{Yurikov Oleksandr. Exemption from serving punishment with trial for committing corruption criminal offenses and criminal offenses related to corruption on the basis of agreements}

The article analyzes the problematic issues of release from serving a sentence with probation for committing corrupt criminal offenses and criminal offenses related to corruption on the basis of a conciliation agreement or a guilty plea.

Conflicts between some provisions of the Criminal Code of Ukraine and the Criminal Procedure Code of Ukraine on release from serving a probation sentence for committing corruption offenses 
and criminal offenses related to corruption on the basis of agreements have been revealed.

The case law of the High Specialized Court of Ukraine for Civil and Criminal Cases, as well as the High Anti-Corruption Court on the outlined issue was studied, on the basis of which it was argued that the judiciary on reconciliation or on admission of guilt should not take into account the provisions of Part 1 of Art. 75 of the Criminal Code of Ukraine, and therefore in case of approval of the above agreement it is possible to release a person from serving a sentence with probation, in particular in case of conviction for a corruption offense or a criminal offense related to corruption.

Based on the analysis of the draft law of February 23, 2021 № 5137 "On Amendments to the Criminal Code of Ukraine and the Criminal Procedure Code of Ukraine to avoid punishment for corruption offenses" it is substantiated that the proposed legislative amendments to the Criminal Code of Ukraine and the Criminal Procedure Code of Ukraine are obsolete fully meet the needs of law enforcement in the field of anti-corruption.

Given the direction of the state's anti-corruption policy, amendments to the Criminal Code of Ukraine and the Criminal Procedure Code of Ukraine have been proposed in order to address the issue of unambiguous interpretation of Art. 75 of the Criminal Code of Ukraine, as well as the correct application of the provisions of criminal and criminal procedure legislation of Ukraine in order to combat corruption by establishing an absolute ban on releasing a person who has committed a corruption or corruption-related criminal offense from criminal liability, punishment or serving.

Key words: criminal offense, agreement, reconciliation, guilt, corruption, criminal liability, punishment, release, probation, probation.

Постановка проблеми. Законом України від 14 жовтня 2014 р. № 1698-VII «Про Національне антикорупційне бюро України» до Кримінального кодексу (далі - КК) України було внесено низку змін, зокрема у примітці до ст. 45 КК України визначено перелік корупційних кримінальних правопорушень, а Законом України від 29 червня 2021 р. № 1576-IX «Про внесення змін до Кодексу України про адміністративні правопорушення, Кримінального кодексу України щодо вдосконалення відповідальності за декларування недостовірної інформації та неподання суб'єктом декларування декларації особи, уповноваженої на виконання функцій держави або місцевого самоврядування» у примітку до ст. 45 КК України було внесено зміни, якими також передбачено перелік кримінальних правопорушень, пов'язаних із корупцією. Ці нововведення зумовлені потребою протидії корупції не лише цивільно- чи адміністративно-правовими засобами, а й кримінально-правовими.

Законодавець також встановив заборону на звільнення від кримінальної відповідальності за вчинення корупційних кримінальних правопорушень і кримінальних правопорушень, пов'язаних із корупцією, на підставі ст. ст. 45, 46, 47, 48 КК України та від покарання чи його відбування на підставі ст. ст. 74, 75, 79 81, 86, 89, 91 КК України, що є одним з ефектив- них кримінально-правових засобів протидії корупційним виявам. Таким способом було окреслено напрям державної політики у сфері протидії корупції - посилення відповідальності й утвердження принципу невідворотності покарання [1]. Однак у кримінальному законодавстві України залишилася можливість уникати «реального» покарання за свої діяння для осіб, які вчинили зазначені вище кримінальні правопорушення. Неоднозначне тлумачення положень ст. 75 КК України «Звільнення від відбування покарання з випробуванням» надає можливість на підставі угоди про примирення чи про визнання винуватості звільняти від відбування покарання з випробування осіб, які вчинили корупційні кримінальні правопорушення чи кримінальні правопорушення, пов'язані з корупцією.

Аналіз останніх досліджень і публікацій. Питання звільнення від відбування покарання з випробуванням за вчинення корупційних кримінальних правопорушень і кримінальних правопорушень, пов'язаних із корупцією, досліджували у своїх працях такі українські та зарубіжні вчені, як: А.В. Андреєв, П.П. Андрушко, B.I. Борисов, О.О. Дудоров, О.О. Кваша, О.О. Книженко, В.В. Кузнецов, М.І. Мельник, Є.О. Письменський, А.В. Савченко, В.О. Туляков, В.В. Чернєй, С.С. Чернявський, В.I. Шакун та інші. Праці цих 
науковців мають вагоме наукове та практичне значення, однак питання щодо абсолютної заборони на звільнення від відбування покарання з випробуванням за вчинення корупційних кримінальних правопорушень і кримінальних правопорушень, пов'язаних із корупцією, на підставі угод залишається недослідженим.

Тому метою статті $\epsilon$ висвітлення особливостей звільнення від відбування покарання з випробуванням за вчинення корупційних кримінальних правопорушень і кримінальних правопорушень, пов'язаних із корупцією, на підставі угод, а також формування пропозицій щодо встановлення абсолютної заборони на звільнення від відбування покарання з випробуванням осіб, які вчинили зазначені вище кримінальні правопорушення.

Виклад основного матеріалу. Законом України від 13 квітня 2012 р. № 4652-VI «Про внесення змін до деяких законодавчих актів у зв'язку із прийняттям Кримінального процесуального кодексу України» було внесено такі зміни до КК України: 1) ст. 65 доповнено ч. 5 в такій редакції: «У випадку затвердження вироком угоди про примирення або про визнання вини суд призначає покарання, узгоджене сторонами угоди»; 2) ст. 75 доповнено новою ч. 2 в такій редакції: «Суд приймає рішення про звільнення від відбування покарання 3 випробуванням у випадку затвердження угоди про примирення або про визнання вини, якщо сторонами угоди узгоджено покарання у виді виправних робіт, службового обмеження для військовослужбовців, обмеження волі, позбавлення волі на строк не більше п'яти років, а також узгоджено звільнення від відбування покарання з випробуванням» $[2 ; 3]$. Це об'єднало кримінально-процесуальний інститут кримінального провадження на підставі угод і кримінальноправовий - призначення покарання та звільнення від його відбування.

Зазначені новели спричинили певні проблеми під час правозастосування в частині звільнення особи від відбування покарання з випробуванням на підставі угод. Попри встановлену законодавцем заборону звільняти від кримінальної відповідальності чи від покарання або його відбування осіб, які вчинили корупційні кри- мінальні правопорушення або кримінальні правопорушення, пов'язані з корупцією, ч. 2 ст. 75 КК України надає таку можливість шляхом укладення угоди про примирення чи про визнання винуватості.

Відповідно до ч. ч. 1, 3 ст. 469 КПК України, угода про примирення може бути укладена за ініціативою потерпілого, підозрюваного або обвинуваченого. Домовленості стосовно угоди про примирення можуть проводити самостійно потерпілий і підозрюваний чи обвинувачений, захисник і представник або за допомогою іншої особи, погодженої сторонами кримінального провадження (крім слідчого, прокурора або судді). Угода про примирення між потерпілим і підозрюваним чи обвинуваченим може бути укладена у провадженні щодо кримінальних проступків, нетяжких злочинів і у кримінальному провадженні у формі приватного обвинувачення. Укладення угоди про примирення у кримінальному провадженні щодо уповноваженої особи юридичної особи, яка вчинила кримінальне правопорушення, у зв'язку 3 яким здійснюється провадження щодо юридичної особи, не допускається [4].

Відповідно до ч. ч. 2, 4 ст. 469 КПК України, угода про визнання винуватості може бути укладена за ініціативою прокурора або підозрюваного чи обвинуваченого у провадженні щодо: 1) кримінальних проступків, нетяжких злочинів, тяжких злочинів; 2) особливо тяжких злочинів, віднесених до підслідності НАБУ за умови викриття підозрюваним чи обвинуваченим іншої особи у вчиненні злочину, віднесеного до підслідності НАБУ, якщо інформація щодо вчинення такою особою злочину буде підтверджена доказами; 3) особливо тяжких злочинів, учинених за попередньою змовою групою осіб, організованою групою чи злочинною організацією або терористичною групою за умови викриття підозрюваним, який не $\epsilon$ організатором такої групи або організації, кримінально протиправних дій інших учасників групи чи інших, учинених групою або організацією злочинів, якщо повідомлена інформація буде підтверджена доказами [4].

Під час вирішення питання про укладення угоди про визнання винуватості необхідно враховувати такі обставини: 1) ступінь і характер сприяння підозрюва- 
ного чи обвинуваченого у проведенні кримінального провадження щодо нього або інших осіб; 2) характер і тяжкість обвинувачення (підозри); 3) наявність суспільного інтересу в забезпеченні швидшого досудового розслідування та судового провадження, викритті більшої кількості кримінальних правопорушень; 4) наявність суспільного інтересу в запобіганні, виявленні чи припиненні більшої кількості кримінальних правопорушень або інших більш тяжких кримінальних правопорушень [4]. Встановлення зазначених обставин у разі укладання угоди про примирення Кримінальний процесуальний кодекс (далі - КПК) України не вимагає.

3 огляду на зазначене вище можна стверджувати, що заборони стосовно укладання угод у кримінальному провадженні щодо корупційних кримінальних правопорушень і кримінальних правопорушень, пов'язаних із корупцією, у КПК України не встановлено. Отже, в осіб, яких підозрюють (обвинувачують) у вчиненні зазначених вище кримінальних правопорушень, є можливість «домовитися» із правоохоронними органами про звільнення від відбування покарання з випробуванням. Цим нерідко зловживають правозастосувачі, які використовують положення ч. 2 ст. 75 КК України як «відкуп» від «реального» покарання. Звісно, звільнення особи від відбування покарання з випробуванням $\epsilon$ заохочувальним засобом кримінально-правового впливу держави, який застосовують суди до винних осіб з огляду на тяжкість кримінального правопорушення, особу винного й інші обставини справи. Однак невирішеним залишається питання: чому суб'єкти правозастосування не враховають ч. 1 ст. 75 КК України, яка встановлює заборону застосовувати такий вид звільнення від відбування покарання в разі засудження за корупційне кримінальне правопорушення та кримінальне правопорушення, пов'язане з корупцією? [3].

Зазначена колізія виникла у зв'язку з тим, що чинні КК України і КПК України регулюють два різновиди звільнення від відбування покарання з випробуванням: 1) загальний - коли вимагається встановлення можливості виправлення засудженого без відбування покарання; 2) спеці- альний - у разі затвердження угоди про примирення чи про визнання винуватості, для укладення якої з'ясування питань, визначених у ч. 1 ст. 75 КК України, не $\epsilon$ обов'язковим. У зв'язку із чим, якщо сторони узгодили покарання та досягли домовленості щодо звільнення підозрюваного (обвинуваченого) від відбування його з випробуванням, відповідно до ч. ч. 2, 3 ст. 75 КК України, суд зобов'язаний ухвалити рішення про таке звільнення в разі затвердження угоди про примирення чи про визнання винуватості за наявності сукупності таких умов: 1) сторони угоди узгодили покарання у виді виправних робіт, службового обмеження для військовослужбовців, обмеження волі, позбавлення волі на строк не більше ніж п'ять років; 2) узгоджено звільнення від відбування покарання з випробуванням; 3) угода відповідає чинному законодавству, підстав для відмови в ії затвердженні, визначених у КПК України (п. 1-6 4. 7 ст. 474 КПК України), немає [5].

Тобто судові органи сформували правову позицію, згідно з якою під час вирішення питання про звільнення від відбування покарання з випробуванням на підставі укладеної угоди про примирення чи про визнання винуватості не враховують положення ч. 1 ст. 75 КК України, а тому в разі затвердження зазначеної вище угоди можна звільнити особу від відбування покарання із встановленням випробувального строку, зокрема в разі іï засудження за корупційне кримінальне правопорушення або кримінальне правопорушення, пов'язане з корупцією $[5 ; 6]$. Однак висловлюють і критичні погляди на окреслену правову позицію. Деякі судді вважають, що ч. 2 ст. 75 КК України не $\epsilon$ спеціальною нормою, а $\epsilon$ похідною від ч. 1 ст. 75 КК України, у зв'язку із чим не може бути застосована судом окремо від норми ч. 1 ст. 75 КК України. Такий підхід $\epsilon$ слушним, оскільки він ґрунтується на тому, що суд може ухвалити рішення про звільнення особи від відбування покарання з випробуванням суто за умови, якщо він дійде висновку про можливість ії̈ виправлення без відбування покарання. Ця умова міститься лише в ч. 1 ст. 75 КК України, її немає в ч. 2 ст. 75 КК України, у зв'язку із чим окремо ії застосувати не 
можна, а оскільки ч. 1 ст. 75 КК України забороняє звільнення особи від відбування покарання за корупційне кримінальне правопорушення та кримінальне правопорушення, пов'язане з корупцією, то ця заборона поширюється також і на випадки затвердження угод. Звільнення ж особи від відбування покарання з випробуванням за відсутності зазначеної умови спотворює мету покарання та не відповідає завданням кримінального провадження, які визначені ст. 2 КПК України [7].

3 метою уникнення неоднозначного тлумачення ст. 75 КК України 23 лютого 2021 р. до Верховної Ради України було подано законопроєкт № 5137 «Про внесення змін до Кримінального кодексу України та Кримінального процесуального кодексу України з метою невідворотності покарання за корупційні кримінальні правопорушення», яким запропоновано внести такі зміни: 1) ч. 2 ст. 75 КК України викласти в такій редакції: «Суд, з урахуванням вимог ч. 1 цієї статті, ухвалює рішення про звільнення від відбування покарання з випробуванням у разі затвердження угоди про примирення або про визнання вини, якщо сторонами угоди узгоджено покарання у виді виправних робіт, службового обмеження для військовослужбовців, обмеження волі, позбавлення волі на строк не більше п'яти років, а також узгоджено звільнення від відбування покарання з випробуванням»; 2) ст. 471 КПК України доповнено ч. 2 такого змісту: «Угода про примирення у кримінальному провадженні за підозрою чи обвинуваченням у вчиненні кримінального правопорушення, яке належить до корупційних кримінальних правопорушень згідно із приміткою до ст. 45 КК України, не може передбачати звільнення від відбування покарання з випробуванням»; 3) ст. 472 КПК України доповнено ч. 2, яку викладено в зазначеній вище редакції стосовно угоди про визнання винуватості [8].

Цілком поділяємо позицію законодавця щодо встановлення абсолютної заборони на звільнення осіб від кримінальної відповідальності, покарання чи його відбування за вчинення корупційних кримінальних правопорушень і кримінальних правопорушень, пов'язаних із корупцією. Із запропонованих у зазначеному вище законопроєкті змін слушним видається рішення передбачити в ч. 2 ст. 75 КК України обов'язок ураховувати положення ч. 1 цієї статті під час вирішення питання про звільнення від відбування покарання з випробуванням на підставі угоди.

Водночас уважаємо, що деякі запропоновані законодавцем зміни не цілком відповідають потребам правозастосовної практики у сфері протидії корупції. По-перше, у ч. 2 ст. 75 КК України використано поняття «угода про визнання вини», натомість в інших статтях КК України та КПК України - це «угода про визнання винуватості». 3 метою уникнення колізій між КК України та КПК України пропонуємо в ч. 5 ст. 65 і ч. 2 ст. 75 КК України слово «вини» замінити словом «винуватості». По-друге, для ефективної протидії корупції кримінально-правовими засобами варто заборонити звільняти від відбування покарання з випробуванням не лише в разі засудження за корупційні кримінальні правопорушення, а й за кримінальні правопорушення, пов'язані з корупцією. У зв'язку із цим пропонуємо ст. 471 КПК України доповнити ч. 2 такого змісту: «Угода про примирення у кримінальному провадженні за підозрою чи обвинуваченням у вчиненні кримінального правопорушення, яке належить до корупційних кримінальних правопорушень або кримінальних правопорушень, пов'язаних із корупцією, згідно із приміткою до ст. 45 КК України, не може передбачати звільнення від відбування покарання з випробуванням». Окрім того, ст. 472 КПК України доповнити ч. 2 такого змісту: «Угода про визнання винуватості у кримінальному провадженні за підозрою чи обвинуваченням у вчиненні кримінального правопорушення, яке належить до корупційних кримінальних правопорушень або кримінальних правопорушень, пов'язаних із корупцією, згідно із приміткою до ст. 45 КК України, не може передбачати звільнення від відбування покарання з випробуванням».

Запропоновані зміни в разі запровадження їх стануть ефективним кримінально-правовим засобом протидії корупції в Україні, що, по-перше, унеможливить звільнення винних від кримінальної відповідальності, покарання чи його відбування за вчинення корупційних кримі- 
нальних правопорушень і кримінальних правопорушень, пов'язаних із корупцією; по-друге, здійснюватиме превентивну функцію щодо вчинення зазначених вище кримінальних правопорушень, оскільки особа усвідомлюватиме, що можливості уникнути «реального» покарання немає, що зменшить кількість корупційних виявів.

Висновки. Нині у КК України не встановлено абсолютної заборони на звільнення винних від кримінальної відповідальності, покарання чи його відбування в разі вчинення корупційних кримінальних правопорушень і кримінальних правопорушень, пов'язаних із корупцією, що створює умови для нових корупційних виявів.

Запропоновані законодавцем зміни до КК України та КПК України, які викладені в законопроєкті «Про внесення змін до Кримінального кодексу України та Кримі- нального процесуального кодексу України з метою невідворотності покарання за корупційні кримінальні правопорушення» уже $є$ застарілими й не забезпечать ефективної протидії корупції.

3 огляду на потреби правозастосування та змісту розглянутого вище законопроєкту було запропоновано зміни до КК України та КПК України, які унеможливлюють звільнення від відбування покарання за вчинення корупційних кримінальних правопорушень і кримінальних правопорушень, пов'язаних із корупцією, на підставі угод.

У разі запровадження запропонованих змін буде встановлено абсолютну заборону на звільнення осіб від кримінальної відповідальності, покарання чи його відбування в разі вчинення зазначених вище кримінальних правопорушень.

\section{ЛITEPATУРA:}

1. Про внесення змін до Кримінального кодексу України та Кримінального процесуального кодексу України з метою невідворотності покарання за корупційні кримінальні правопорушення : пояснювальна записка до проєкту закону України від 23 лютого 2021 р. № 5137. URL: http://w1.c1.rada.gov.ua/pls/zweb2/webproc4_1?pf3511=71209

2. Про внесення змін до деяких законодавчих актів у зв'язку із прийняттям Кримінального процесуального кодексу України : Закон України від 13 квітня 2012 р. № 4652-VI. URL: https://zakon.rada.gov.ua/laws/show/4652-17\#Text

3. Кримінальний кодекс України : Закон України від 5 квітня 2001 р. № 2341-III. URL: https://zakon.rada.gov.ua/laws/show/2341-14\#n3384

4. Кримінальний процесуальний кодекс України : Закон України від 13 квітня 2012 р. № 4651-VI. URL: https://zakon.rada.gov.ua/laws/show/4651-17\#Text

5. Про практику здійснення судами кримінального провадження на підставі угод : постанова Пленуму Вищого спеціалізованого суду України з розгляду цивільних і кримінальних справ від 11 грудня 2015 р. № 13. URL: https://zakon.rada.gov.ua/laws/show/v0013740-15\#Text

6. Вирок Вищого антикорупційного суду від 23 вересня 2020 р. № 991/7534/20 (провадження № 1-кп/991/69/20). URL: https://reyestr.court.gov.ua/Review/91734953

7. Окрема думка судді Вищого антикорупційного суду Ткаченка О.В. до вироку від 23 вересня 2020 р. № 991/7534/20 (провадження № 1-кп/991/69/20). URL: https://reyestr.court.gov.ua/Review/91764712

8. Про внесення змін до Кримінального кодексу України та Кримінального процесуального кодексу України з метою невідворотності покарання за корупційні кримінальні правопорушення : проєкт закону України від 23 лютого 2021 р. № 5137. URL: http://w1.c1.rada.gov.ua/pls/zweb2/webproc4_1?pf3511=71209 